DOI: $10.15290 /$ bsl.2018.13.07

\title{
Elżbieta Dutka
}

Wydział Filologiczny

Uniwersytet Śląski w Katowicach

e-mail: elzbieta.dutka@us.edu.pl

ORCID: 0000-0002-5404-2586

\section{Przestrzeń i tożsamość. Dylematy „człowieka gór” w twórczości Michała Jagiełły}

W humanistyce po „zwrocie przestrzennym” są zarówno podejmowane próby reinterpretacji tradycyjnych koncepcji tożsamości opartych na przypisaniu i przywiązaniu do miejsca (urodzenia, zamieszkiwania), poczuciu zadomowienia, jak i formułowane nowe ujęcia podmiotowości wykorzystujące kategorie spacjalne ${ }^{1}$. Na przykład poszerzany jest stan badań na temat tożsamości regionalnej², a równolegle pojawiają się studia o tożsamości transgranicznej i koncepcjach związanych z doświadczeniami nieprzynależności, migracji, nomadyzmu ${ }^{3}$. Problemami przestrzennych samoidentyfikacji, lokalizowania podmiotu zajmuje się wielu badaczy, między innymi Małgorzata Czermińska ${ }^{4}$, Ewa Rewers ${ }^{5}$, Aleksandra Kunce ${ }^{6}$. Elżbieta Rybicka

1 E. Rybicka, Geopoetyka. Przestrzeń i miejsce we wspótczesnych teoriach i praktykach literackich, Kraków 2014, s. 243-244.

2 Zob. np. J. Kijonka, Tożsamość współczesnych Górnośląaków. Studium socjologiczne, Katowice 2016.

3 Zob.np. Region a tożsamości transgraniczne. Literatura. Miejsca. Translokacje, red. D. Zawadzka, M. Mikołajczak, K. Sawicka-Mierzyńska, Kraków 2016.

4 M. Czermińska, Tożsamość kształtowana w pamięci miejsca, „Ruch Literacki” 2013, nr 6, s. 591-606.

5 E. Rewers, Miejsce podmiotu - podmiot jako miejsce. Kto wyprowadza podmiot z metafizyki?, „Er(r)go" 2000, nr 1, s. 21-34; tejże, Więźniowie transkulturowej wyobraźni, „Teksty Drugie” 2004, nr 4, s. 28-39.

6 A. Kunce, Człowiek lokalny. Rozważania umiejscowione, Katowice 2016. 
w pracy Geopoetyka. Przestrzeń $i$ miejsce we współczesnych teoriach $i$ praktykach literackich przybliża koncepcję Roberta Davida Sacka - homo geographi$\mathrm{Cus}^{7}$, a także nawiązujące do niej propozycje Jacka Kaczmarka i Mikołaja Madurowicza $^{8}$. W ujęciu pierwszego $\mathrm{z}$ nich wyeksponowany został rozciągnięty w czasie i przestrzeni proces tożsamościowy - swego rodzaju "wędrowanie", drugi podkreśla istotę utożsamienia z miejscem, jako gwarantem integralności, ale i zwraca uwagę na odpowiedzialność człowieka za nie. W kontekście przestrzennych dyskursów tożsamościowych chciałabym zwrócić uwagę na szczególny przypadek, gdy tożsamość jest określana w odniesieniu do specyficznego środowiska i wyjątkowej formacji krajobrazowej jaką są góry.

Zarys "górskiej" tożsamości z perspektywy filozoficznej przedstawiła Antonina Sebesta w rozprawie Etyka $i$ ethos "ludzi gór"9. Badaczka pisze, że termin "człowiek gór" jest używany od ponad stu lat w języku potocznym, piśmiennictwie, a także $\mathrm{w}$ mediach ${ }^{10}$, jednak wciąż nie został $\mathrm{w}$ wyczerpujący sposób zdefiniowany. Przypomnieć tu można podobną opinię literaturoznawcy Jacka Kolbuszewskiego, który już wcześniej uznał pytanie o „człowieka gór" za główny, ale rozwiązany jedynie w "nikły sposób” problem literatury taternickiej $\mathrm{w}$ pierwszych czterech dekadach $\mathrm{XX}$ wieku ${ }^{11}$. O ważności problemu świądczy także stwierdzenie należącej do wspinaczkowej wspólnoty Haliny Ptakowskiej-Wyżanowicz: „O ludziach gór wiele napisano książek". Autorka prekursorskiej monografii na temat kobiecego taternictwa sama wyjaśnia w dość enigmatyczny i charakterystyczny dla wielu różnych publikacji sposób, że „ludzie gór” to osobnicy „uczuleni na góry”. Przypadłość ta objawia się - jej zdaniem - tęsknotą za szczytami i przełęczami, gdy jest się daleko i "gorącymi uczuciami", odczuwanymi najsilniej wtedy, gdy ma się „pod stopami strome ścieżki”, gdy można wciągnąć w płuca zapach tatrzańskich regli lub odpoczywać wśród skał po trudzie wspinaczki ${ }^{12}$. W wielokrotnie wznawianych Wędrówkach alpejskich Wawrzyńca Żuławskiego znalazła się w niewielkim stopniu dokładniejsza charakterystyka:

\footnotetext{
7 E. Rybicka, Geopoetyka. Przestrzeń i miejsce we współczesnych teoriach i praktykach literackich, s. 244-245.

8 Zob. J. Kaczmarek, Podejście geobiograficzne w geografii społecznej. Zarys teorii i podstawy metodycznej, Łódź 2005; M. Madurowicz, Tożsamość homo localis w geografii człowieka, w: Człowiek w badaniach geograficznych, red. W. Maik, K. Rembowska, A. Suliborski, Bydgoszcz 2006.

9 A. Sebesta, Etyka i ethos "ludzi gór", Zakopane 2014.

10 Tamże, s. 21-36.

11 J. Kolbuszewski, Przedmowa, w: Czarny szczyt. Proza taternicka lat 1904-1939, wybór, oprac. i przedm. J. Kolbuszewski, Kraków 1976, s. 21.

12 H. Ptakowska-Wyżanowicz, Od krynoliny do liny, Warszawa 1960, s. 7.
} 
Ustawiczne zmagania z przyrodą, które toczy alpinista, nie tylko hartują jego ciało, nerwy i wolę. Rozwijają w nim również cechy głęboko humanistyczne, poczucie wspólnoty ludzkiej, poczucie koleżeństwa, chęć niesienia pomocy każdemu, kto jej potrzebuje. Gdy spotka się na szlaku prawdziwego człowieka gór, można być zawsze pewnym jego pomocy we wszystkich okolicznościach ${ }^{13}$.

Inny alpinista - Adam Bilczewski przekonuje: „wszystkich nas łączy pasja gór"14. Powszechne jest także przekonanie, że członków wspominanej wspólnoty wyróżnia nie tylko skłonność do autorefleksji, dla której punktem odniesienia są szczyty, ale i duży indywidualizm, czasami nawet egocentryzm $^{15}$. Koncepcję tożsamości budowanej na związku z górami jako formę samorealizacji, podążania własną „ścieżką góry”, współcześnie promuje - na przykład - poprzez swoją alpinistyczną działalność i pisarstwo Wojciech Kurtyka - bohater opublikowanej niedawno biografii autorstwa Bernadette McDonald ${ }^{16}$.

Antonia Sebesta zauważa, że szeroki zakres znaczeniowy pojęcia „człowiek gór", rozmycie kryteriów i różne użycia utrudniają jego zdefiniowanie. O pojemności i wieloznaczności terminu, rozpiętego pomiędzy emocjami, patosem i zawężającym profesjonalizmem, ale może przede wszystkim o potrzebie i zasadności refleksji na ten temat, świadczyć może szósty tom Wielkiej encyklopedii gór i alpinizmu, redagowanej przez Małgorzatę i Jana Kiełkowskich, zatytułowany właśnie Ludzie gór. We wstępie wydawca - Stanisław Pisarek pisze z emfazą, że „ludzie gór to inna nacja, inny świat. To romantycy, marzyciele, zdobywcy i twórcy" ${ }^{17}$, natomiast redaktorzy w swojej nocie rzeczowo wyjaśniają:

tom w całości poświęcony jest ludziom gór, taternikom i alpinistom, współczesnym wspinaczom skalnym, sportowym i rekordzistom, a także eksploratorom, odkrywcom, uczonym, artystom - wszystkim, których działalność przyczyniła się najpierw do udostępnienia, a później do systematycznego poznawania świata gór ${ }^{18}$.

${ }^{13}$ W. Żuławski, Wędrówki alpejskie, w: tegoż, Sygnały ze skalnych ścian, Tragedie tatrzańskie, Wędrówki alpejskie, Skalne lato, Warszawa 1967, s. 237.

14 A. Bilczewski, Od autora, w: tegoż, Alpiniści, Katowice 1987, s. 5.

15 Ton krytyczny i sprzeciw wobec idealizacji „ludzi gór" pobrzmiewa np. w rozprawie Z. Klemensiewicza, Społeczna wartość taternictwa, w: Czarny szczyt. Proza taternicka lat 1904-1939, s. 89.

16 B. McDonald, Kurtyka. Sztuka wolności, przeł. M. Krupa, Warszawa 2018.

17 S. Pisarek, Od wydawcy, w: Wielka encyklopedia gór i alpinizmu, red. M. i J. Kiełkowscy, t. 6 Ludzie gór, Katowice 2013, s. VII.

18 M. i J. Kiełkowscy, Od redakcji, w: Wielka encyklopedia gór i alpinizmu, red. M. i J. Kiełkowscy, t. 6 Ludzie gór, s. IX. 
Ponadto często przy okazji definiowania tożsamości „ludzi gór” w grę wchodzą emocje, ujawniające się $\mathrm{w}$ pełnych patosu deklaracjach na temat miłości do gór ${ }^{19}$, uznawaniu ich potęgi ${ }^{20}$ czy absolutyzacji gór, postrzeganych jako ostoja wszelkich wartości ${ }^{21}$. Z tego względu wydaje się, że pojęcie „człowieka gór" bliższe jest taternickiej postawie romantycznej, choć w dyskusjach na ten temat głos zabierają również przedstawiciele podejścia sportowego ${ }^{22}$. Ze względu na przenoszenie (niejako automatyczne, choć irracjonalne) znaczeń przypisywanych w kulturze górom (często związanym ze sferą sacrum) na tych, którzy je pokonują, zdobywają, zadanie komplikuje się jeszcze bardziej. Oczekiwania etyczne wobec „ludzi gór" są wysokie - „wręcz na miarę szczytów", jak pisze Antonina Sebesta ${ }^{23}$. Dlatego szczególnie uzasadnione wydaje się mówienie o etyce i ethosie tej grupy. Od „człowieka gór" oczekuje się heroizmu, istotą jego działań są zmagania ze sobą, z własnymi słabościami, samotnością, oporem przestrzeni - warunkami atmosferycznymi, itp. Ale poczucie przynależności do tak wyjątkowej, wręcz elitarnej wspólnoty nadal wiąże się $\mathrm{z}$ niebezpieczeństwem popadnięcia $\mathrm{w}$ pułapkę narcyzmu lub snobizmu, trudno ustrzec się przed patrzeniem „z góry” na rzesze „zwykłych" turystów. Z jednej strony powszechne jest przekonanie, że „ludzie gór" to indywidualiści, często nawet samotnicy uciekający na szczyty od świata. $\mathrm{Z}$ drugiej strony - równie często w charakterystykach tego typu osobowości dużo miejsca poświęca się ideom górskiego partnerstwa - „braterstwa liny", ideom związanym $\mathrm{z}$ ratownictwem.

Fundamentalny dla omawianej koncepcji tożsamości jest bliski, wręcz intymny stosunek do wybranej przestrzeni. Prowadzi on do przekonania, że tylko tam żyje się „pełnią życia”, że w "górach jest wszystko, co kocham" ${ }^{24}$.

19 Przykłady można odnaleźć w antologii cytatów i sentencji pod tytułem Miłość gór, zebrał i oprac. K. Mikucki, Kraków 2011.

20 Potęga gór, zebrał i oprac. K. Mikucki, zdjęcia P. Dróżdż, Kraków 2017.

21 Jacek Kolbuszewski stwierdza: „Absolutyzacja gór czyni z nich wartość nadrzędną wobec wszystkich innych, stając się symbolem wielkich wartości człowieka" [J. Kolbuszewski, W stronę współczesności, w: tegoż, Tatry. Literacka tradycja motywu gór, Kraków 1995, s. 167]. Takie stanowisko - zdaniem badacza - reprezentowane jest w tomie Aleksandra Wojciechowskiego, Tatrzańskie, Poznań 1982 i w poezji Marii Kaloty-Szymańskiej, Sezon w Tatrach i po sezonie, Gdańsk 1981.

22 Podział na przedstawicieli romantycznego (przyznającego wspinaczce wyjątkowe wartości) i sportowego podejścia do gór uwypuklił się wyraźnie już w dwudziestoleciu międzywojennym w dyskusjach na temat ideologii taternictwa, a także Tatr jako parku narodowego, pustyni i boiska. Reprezentantami pierwszej postawy są m.in. J.G. Pawlikowski, M. Karłowicz, M. Zaruski, a drugiej - J.A. Szczepański. Zob. Czarny szczyt. Proza taternicka lat 1904-1939.

23 A. Sebesta, Etyka i ethos "ludzi gór", s. 17.

24 „W górach jest wszystko co kocham" - takie słowa zamieszczono w Bieszczadach na 
Czasami ma to postać emocjonalnego uzależnienia (sformułowanie „narkotyk gór" stało się tytułem opowiadania i całego zbioru Rafała Malczewskiego ${ }^{25}$ ), bywa formą sublimacji, poszukiwania sensu własnej egzystencji, drogą kreacji siebie i samorealizacją lub po prostu życiową pasją. Zazwyczaj emocjonalny związek $\mathrm{z}$ górami przejawia się $\mathrm{w}$ potrzebie bezpośredniego doświadczania gór, które nie są oglądane z perspektywy hotelu czy kolejki wiozącej wygodnie na szczyt, lecz "przechodzone" na własnych nogach.

$Z$ definiowaniem tożsamości w oparciu o doświadczanie przestrzeni górskiej często związana jest dobra, bo praktycznie sprawdzona, znajomość topografii, wchodzenie „całym sobą" w krajobraz. Na ogół oznacza ten stosunek także troskę o góry, pragnienie ochrony górskiego krajobrazu przed antropopresją, przed wpływem cywilizacji, prowadzące do postaw proekologicznych. Takie stanowisko ujawniło się już w prekursorskim manifeście Kultura a natura Jana Gwalberta Pawlikowskiego z 1913 roku ${ }^{26}$ czy w najsłynniejszych wystąpieniach Mariusza Zaruskiego, twórcy Tatrzańskiego Ochotniczego Pogotowia Ratunkowego ${ }^{27}$.

Antonina Sebesta zauważa, że w większości krajów alpejskich „ludźmi gór” określa się „przede wszystkim przewodników, ratowników i osoby prowadzące schroniska, czyli tych, którzy są zawodowo stale z nimi związani" ${ }^{28}$. Potwierdzałby to popularny internetowy "portal górski”, którego jedna z zakładek - zatytułowana właśnie Ludzie gór zawiera przede wszystkim artykuły i informacje o wybitnych wspinaczach, narciarzach, biegaczach górskich ${ }^{29}$. W kulturze polskiej wąskie, „profesjonalne”, a nawet elitarne definicje "człowieka gór" (który zawodowo i twórczo jest związany ze skalnym światem wierchów, oddaje mu wręcz całe swoje życie) bywa często rozszerzane na tych wszystkich, którzy na różne sposoby doświadczają gór. Wyznacznikiem wówczas jest wspominana już potrzeba przebywania $\mathrm{w}$ takim środowisku, wrażliwość na górskie piękno. Ze względu na szeroki zakres

Przełęczy Wyżnej pod Połoniną Wetlińską na pomniku upamiętniającym Jerzego Harasymowicza. Przywołany wers, rozpoczynający wiersz tego poety zatytułowany $W$ górach stał się sentencją, jest także tytułem "portalu poetycko-muzycznego ludzi chodzących po górach” http://www.wgorach.art.pl [dostęp 23.05.2018].

25 R. Malczewski, Narkotyk gór. Nowele, Warszawa 1928.

26 J.G. Pawlikowski, Kultura a natura i inne manifesty ekologiczne, wybór, oprac., red. R. Okraska, Łódź 2010.

27 M. Zaruski, Tatry jako pustynia, w: tegoż, Na bezdrożach tatrzańskich. Wycieczki, wrażenia i opisy, Łomianki 2007, s. 15-19; tegoż, O istocie alpinizmu, w: tegoż, Na bezdrożach tatrzańskich. Wycieczki, wrażenia i opisy, s. 20-26.

28 A. Sebesta, Etyka i ethos „ludzi gór", s. 31.

29 www.portalgorski.pl/artykuly/ludzie-gor [dostęp 30.03.2018]. 
przywołanej definicji, konieczne wydaje się dokonanie pewnej typologii. Antonina Sebesta wyróżnia "ludzi gór” i „synów gór”. Do pierwszej grupy zalicza się osoby świadomie (zawodowo lub hobbystycznie) wiążące swoje życie $\mathrm{z}$ górami ${ }^{30}$, do drugiej - górali, czyli osoby urodzone i mieszkające w górach, zwłaszcza od kilku pokoleń. Kategorię „synów gór" do polskiego piśmiennictwa wprowadził Władysław Orkan w przemówieniu wygłoszonym na VI Zjeździe Podhalan w 1922 roku $^{31}$. Filozofka dokonuje również rozróżnienia na „ludzi gór" i „miłośników gór”:

„Ludzie gór" to grupa w znacznej mierze formalizowana przez przynależność do organizacji alpinistycznych, ratowniczych, przewodnickich. „Ludzie gór" stanowią grupę odniesienia dla znacznie liczniejszej rzeszy wytrawnych (doświadczonych) turystów górskich - „miłośników gór", repów górskich (specjaliści używają pojęcia turyści kwalifikowani). [...] Miłośnicy próbują naśladować „ludzi gór". Jest to pozytywny snobizm sprowadzający się do akceptacji ich wartości i norm postępowania. Przejawia się najczęściej w obyczaju pozdrawiana na szlaku, czasem karykaturalnym (np. w sezonie na popularnych szlakach tatrzańskich gdzie zagęszczenie dorównuje miejskiemu) i wymianie informacji, rzadziej okazywaniu drobnej pomocy ${ }^{32}$.

Ponadto filozofka pisze także o „konsumentach górskich wrażeń”, czyli na przykład klientach komercyjnych wypraw, których postawę cechuje pragmatyzm, instrumentalne i merkantylne podejście do gór.

Antonina Sebesta, przytaczając stanowiska literaturoznawcy (Jacka Kolbuszewskiego), historyka sztuki (Jacka Woźniakowskiego), socjologa (Andrzeja Ziemilskiego), lekarza (Zdzisława Ryna), historyka sportu (Andrzeja Matuszyka), a także alpinistów, wspinaczy (m.in. Jana Alfreda Szczepańskiego) zauważa, że zapewne nie istnieje jedna, zadawalająca wszystkich definicja "człowieka gór". Badaczka wylicza jednak pewne wyznaczniki tego pojęcia, takie jak: forma działalności górskiej, intensywność i trwałość kontaktu z górami, stopień ich znajomości, stopień samodzielności działań gór-

\footnotetext{
30 Potwierdzeniem tego może być następujące wprowadzenie do książki francuskiego przewodnika: „Autor, marsalczyk, Gaston Rébuffat (ur. w 1921 r.), nie z urodzenia, ale z wyboru został człowiekiem gór. To, co dla innych było wynikiem oddziaływania środowiska, dziedzictwem zainteresowań a niekiedy i warsztatu pracy, dla niego było powołaniem. Jako chłopiec myślał nie o tym, żeby zostać marynarzem, lecz by żyć wśród gór. Nie pociągały go płaskie brzegi dalekich lądów, ale dużo bliższe, strome krawędzie szczytów. A później, żeby gór nie porzucać, wybrał zawód alpejskiego przewodnika" [J. Wojsznic, [wstęp], w: G. Rébuffat, Gwiazdy i burze. Sześć pótnocnych ścian alpejskich, przeł. Jerzy Kolankowski, Londyn-Kraków 1994, s. 5].

31 A. Sebesta, Etyka i ethos „ludzi gór", s. 23.

32 Tamże s. 36.
} 
skich, miejsce urodzenia i zamieszkania, związki typu zawodowego, twórczego, artystycznego i naukowego, bezinteresowne działania na rzecz gór i osób z nimi związanych lub w nich przebywających ${ }^{33}$.

Określenie "człowiek gór" nieuchronnie nasuwa się na myśl podczas lektury Sztambucha Michała Jagiełty, czyli zbioru wspomnień poświęconych znanemu pisarzowi i taternikowi ${ }^{34}$. Włodzimierz Kalicki „wpisując” się do „sztambucha”, przytoczył rozmowę, podczas której usłyszał następującą samoidentyfikację bohatera tej publikacji: „Człowiek gór, człowiek kultury, chłopski syn" ${ }^{\prime 2}$. Podobną autocharakterystykę odnaleźć można we wstępie do zbioru opowiadań Obsesja $i$ inne góry. Artysta nawiązując do kardynalnej zasady wspinaczki, pisze o swoich "trzech punktach podparcia": zagrodzie, górach i słowie ${ }^{36}$. Wspomniana triada obejmuje kwestie związane z pochodzeniem i rodzinną tradycją (Michał Jagiełło urodził się w 1941 roku w podkrakowskiej wsi Janikowice), fascynacją skalnym światem, z którym w dużym stopniu związał swoje życie (jako taternik, alpinista, przewodnik i ratownik górski, w latach 1972-1974 naczelnik Grupy Tatrzańskiej GOPR) oraz z wykształceniem, zainteresowaniami literackimi i własną twórczością (autor Obsesji ukończył polonistykę na Uniwersytecie Jagiellońskim, w jego dorobku jest zarówno proza jak i tomiki poetyckie ${ }^{37}$ ). Michał Jagiełło pisząc o "trzech punktach podparcia", wprost podsuwa tropy biograficzne, sygnalizuje autobiograficzne konteksty swojego pisarstwa, ale równocześnie podkreśla: „Moje opowiadania i powieści nie są autobiografiami, choć wykorzystuję $\mathrm{w}$ nich - w warstwie zewnętrznej - swoje indywidualne zakorzenie-

33 Tamże s. 35.

34 Sztambuch Michała Jagiełty, autor pomysłu R. Monity, red. K. Wiwer, Kraków 2007. Zob. np.: „Michał Jagiełło to dla mnie człowiek gór, obywatel kultury, pasjonat ludzkich losów” [S. Krajewski, O Michale osobiście, w: Sztambuch Michała Jagiełty, s. 76].

35 W. Kalicki, Między górami a bibliotekami, w: Sztambuch Michała Jagiełty, s. 56.

36 M. Jagiełło, Trzy punkty podparcia, w: tegoż, Obsesja i inne góry, Warszawa 1994, s. 7-15.

37 Dorobek artystyczny M. Jagiełły składa się m.in. z następujących tomów prozatorskich: Hotel klasy lux, Warszawa 1978; Obsesja i inne góry, Warszawa 1994; Trójkątna turnia, Warszawa 1996; Za grania grań, Warszawa 1998; Jawnie i skrycie, Warszawa 2000. Tworzą go również zbiory poetyckie: Goryczka, słodyczka, czas Opowieści, Torun 2007; Sosna i pies. Poemat z zagrody, Warszawa 2008; Ciało i pamięć, Warszawa 2010; Tatry. Koncert na dwóch, zdjęcia K. Wojnarowski, Kraków 2012; Zszywanie - w ucieczce, Warszawa 2014; Pusta drabina, Warszawa 2016. Ponadto M. Jagiełło znany jest także jako autor opracowań naukowych i artykułów popularyzujących góry i turystykę górską. Jego najbardziej popularnym utworem z tego zakresu jest wielokrotnie aktualizowane, zmieniane i wznawiane Wołanie w górach. Wypadki i akcje ratunkowe w Tatrach, pierwsze wydanie tej publikacji ukazało się w Warszawie w 1979 roku, a najnowsze - ósme w 2012 roku również w Warszawie. Drugim kręgiem zainteresowań Michała Jagiełły była historia idei i antropologia kulturowa. 
nie we wsi i zanurzenie w Tatry" ${ }^{38}$. Trzy wymienione elementy są wyraźnie obecne w poezji Michała Jagiełły, doczekały się już literaturoznawczych analiz ${ }^{39}$. Pragnę skoncentrować się na jednym z nich - na górach jako punkcie odniesienia dla poszukiwań tożsamościowych.

Autokomentarz Michała Jagiełły do własnej twórczości można odnaleźć także we wstępie do Wołania w górach. Taternik wyznaje, że pisząc czerpał „pełnymi garściami” ze swojego „zanurzenia się w świat gór, z Tatrami na pierwszym miejscu, i z kontaktów z ludźmi, dla których góry są już to warsztatem pracy zawodowej, już to polem intelektualnej uprawy" ${ }^{40}$. Pisarz podkreśla rolę faktografii i realiów geograficznych, ale także wyjaśnia, że materiał biograficzny został $\mathrm{w}$ jego utworach artystycznie przetworzony:

Jestem obecny w górach i góry są zadomowione we mnie od ponad pięćdziesięciu lat [...]. To zrozumiałe, że myślę czasem: moje góry. Te moje Tatry, te hale i przełęcze, te doliny i szczyty realnie istniejące i zarazem owinięte $\mathrm{w}$ prywatną mitologię starałem się przedstawić $\mathrm{w}$ tryptyku prozy artystycznej [...], a także $\mathrm{w}$ zbiorach poezji [...]. Te wymyślone Tatry i wydumane przygody, którymi obarczyłem swoich bohaterów (bohatera?), są mocno zakorzenione $\mathrm{w}$ moich doświadczeniach górskich, problematyki ratowniczej nie wyłączając. Tu nie ma prostej zależności między moim górskim, dość długim już życiem, a kreacją artystyczną [...] [W, s. 13].

Autor Wołania w górach pisze o sobie jako o „człowieku gór", utożsamia się $\mathrm{z}$ przestrzenią górską, jest $\mathrm{w}$ niej zadomowiony i uznaje ją za swoje miejsce („,moje góry" $\left.{ }^{41}\right)$.

W przywoływanych wcześniej uwagach o "trzech punktach podparcia" pisarz operuje raczej wąską, "profesjonalną" definicją, wyjaśniając, że bohaterowie opowiadań zgromadzonych w tomie Obsesja i inne góry są:

zazwyczaj synami nizin, którzy z wyboru stali się ludźmi gór; są to taternicy, alpiniści, himalaiści oraz niektórzy ratownicy tatrzańscy. Każdy z nich miał ten

38 M. Jagiełło, Trzy punkty podparcia, w: tegoż, Obsesja i inne góry, s. 12.

39 Na temat poezji M. Jagiełły pisze E. Ogłoza, Wieś, Tatry i słowo w liryce Michała Jagiełly, w: Między sacrum i profanum. Rozważania i dylematy, red. G. Różańska, Kraków 2017, s. 41-61. Sporo miejsca twórczości lirycznej tego taternika poświęca w swojej pracy E. Kalus, Skalne olśnienia. Wspótczesna poezja tatrzańsko-podhalańska, Kraków 2016.

${ }^{40}$ M. Jagiełło, Od autora, w: tegoż, Wołanie w górach. Wypadki i akcje ratunkowe w Tatrach, Warszawa 2012, s. 13. W pracy cytaty z tej kroniki ratownictwa tatrzańskiego i osobistego eseju o "górskim życiu” zarazem będę lokalizować bezpośrednio w tekście głównym, stosując skrót W.

41 Takie, nieco „zawłaszczające” określenie również wydaje się bardzo charakterystyczne dla „ludzi gór" - por. W. Bonatti, Moje góry, przeł. B. Norton, Warszawa 1967; W. Krygowski, Góry i doliny po mojemu, Kraków 1977. 
swój pierwszy raz, ten błysk pewności, że góry są mu przypisane na jakiś czas, a może na całe życie. Moi bohaterowie traktują góry jako swe naturalne miejsce wybrane, w którym intensywnie przeżywają dany im czas. Intensywność ta ma pewne cechy choroby: jest to obsesyjna potrzeba analizowania siebie i zarazem unikania niewygodnych pytań. Reakcje mych bohaterów są często bardzo emocjonalne, na granicy histerii, w czym upodobniają się oni do dawnych tatrzańskich wędrowców, starających się oddać w pisanym słowie szok pierwszego spotkania z górami. Bywało przecież i tak, że ten pierwszy wstrząs stawał się iluminacją, od której brał początek proces górskiej inicjacji ${ }^{22}$.

W opowiadaniach ze zbioru Obsesja i inne góry dostrzec można tendencje demaskatorskie i ideę „odbrązowienia” alpinizmu ${ }^{43}$, pokazania go w sposób daleki od uwznioślającej czy mitologizującej poetyki ${ }^{44}$. Utwory w momencie publikacji były czytane jako proza środowiskowa, wręcz utwory „z kluczem”, po latach bardziej uwidaczniają się w nich uniwersalne pytania o istotę alpinizmu, motywacje wspinaczy i ich postawy. Pisarz dystansuje się do podejścia czysto sportowego, nastawionego na osiągnięcie sukcesów wspinaczkowych, pobijanie kolejnych rekordów. Przyznaje, że „wszedł w taternictwo poprzez literaturę typu romantycznego" 45 . Bliską mu tradycję wyznaczają utwory "romantyków gór": Mariusza Zaruskiego i Mieczysława Karłowicza ${ }^{46}$.

Podobne, demaskatorskie tony wobec „ludzi gór”, ale i próbę uchwycenia specyfiki ich tożsamości można także odnaleźć w Wołaniu w górach. Jagiełło pisze tu wprost:

Ludzie gór to istoty ambitne, może nawet za bardzo, to osoby przeczulone na swoim punkcie, a raczej na punkcie tego, co o nich sądzą i mówią inni. Znając trochę siebie i swoje górskie środowisko, zaryzykuję twierdzenie, że ludzie gór, czyli tacy, którzy lokują w działalności górskiej część swoich ambicji, bardzo boją się ośmieszenia [W, s. 39].

\footnotetext{
42 M. Jagiełło, Trzy punkty podparcia, w: tegoż, Obsesja i inne góry, s. 13-14.

43 O krytycyzmie M. Jagiełły wobec środowiska alpinistycznego zaświadcza także fakt, że docenił demaskatorski i kontrowersyjny reportaż J. Hugo-Badera Długi film o miłości. Powrót na Broad Peak (Kraków 2014) - zob. M. Jagiełło, Osobowość artystyczna w górach wysokich, "Nowe Książki" 2014, nr 9, s. 64-65. Spór wokół książki Hugo-Badera zarysowałam w artykule: E. Dutka, Ekstremalne doświadczenia w ekstremalnej "wcieleniówce”. „Długi film o miłości. Powrót na Broad Peak” Jacka Hugo-Badera jako opowieść o niespetnieniu, „Białostockie Studia Literaturoznawcze" 2017, nr 11, s. 257-274.

44 Pisarz w jednym z wywiadów przyznał, że Obsesja jest „tomikiem ułożonym świadomie prowokacyjnie, wyraźnie skrzywionym" [Czerwień i czerń. Z Michałem Jagiełła rozmawia Wacław Sonelski, „Bularz” 1991, s. 25].

45 Tamże.

46 M. Jagiełło nazywa Karłowicza i Zaruskiego „Ojcami Założycielami” w poświęconym im wierszu Po młodym śniegu, w: M. Jagiełło, Tatry. Koncert na dwóch, s. 34.
} 
Pisarz kontynuuje krytykę także $\mathrm{w}$ innym fragmencie opracowania na temat wypadków i akcji ratunkowych w Tatrach:

Ludziom gór, szczególnie w młodym wieku, zagrażają zadufanie i egotyzm. Afirmacja siebie jest wtedy tak silna, że tłumi refleksję nad ograniczonością człowieka. To inni są słabi i lękliwi - nie ja. To inni popełniają błędy. To inni giną. Ja żyję! [W, s. 354]

$\mathrm{Z}$ jednej strony pisarzowi bliskie jest romantyczne podejście do gór, pragnie widzieć we wspinaczce i górskich wędrówkach coś więcej niż sport i formę aktywności ruchowej, z drugiej daleki jest od bezkrytycznej idealizacji środowiska "ludzi gór".

Podczas lektury Wołania w górach, opowiadań, a zwłaszcza wierszy Michała Jagiełły, wąska definicja "człowieka gór" okazuje się niewystarczająca. Własne obserwacje i doświadczenia stają się w twórczości autora Trójkątnej turni punktem wyjścia do refleksji bardziej ogólnych na temat tożsamości kształtowanej $\mathrm{w}$ relacji do skalnego świata. Autor pracy o wypadkach i akcjach ratunkowych w Tatrach wzywa czytelników do "świadomego doznawania gór i świadomego poznawania siebie w górach". W tym miejscu nie stroni od wzniosłych tonów i mocno podkreśla formacyjny charakter górskiego doświadczenia: „Świadomie przeżywane góry wyzwalają w człowieku jego lepszą stronę. Bezinteresowność wysiłku już sama w sobie jest wartościowa” [W, s. 12]. „Potrzeba bywania w górach" wydaje się podstawowym wyznacznikiem tożsamości "ludzi gór". Według pisarza ma ona charakter "wewnętrzny, duchowy, w niektórych przypadkach egzystencjalny", jest „silną potrzebą poszukiwania wartości przez doświadczanie siebie w niecodziennych warunkach" [W, s. 12].

Istotne wydają się określania stosowane przez Jagiełłę, takie jak: bywanie "w górach, a może raczej w obliczu gór", „przeżywanie gór", "górskie życie" [W, s. 12-13], podkreślają one znaczenie tej przestrzeni w procesach samoidentyfikacji. Upodmiotowione góry są już nie tylko miejscem etycznych wyborów, związanych na przykład z decyzją o niesieniu pomocy, mimo niebezpieczeństw, ale stają się także partnerem, aktorem $w$ tym samym dramacie. "Człowiek gór" w świetle utworów Jagiełły jest - jak pisarz podkreśla - „osobowością artystyczną". Każda postać aktywności górskiej, począwszy od spacerów i „pasienia” oczu panoramą z Rusinowej Polany, przez turystykę po alpinizm i ratownictwo to „forma kultury, a nawet jakiegoś rodzaju działalność twórcza" [W, s. 12]. Poświadczają to często odwołania do sztuki, zwłaszcza dramatu i teatru: „Ten, kto wchodzi w góry i od tego momentu jest scenarzystą, aktorem i reżyserem spektaklu pod tytułem: «Jestem w górach»" [W, s. 15] - pisze Michał Jagiełło. W wierszach pojawiają się także po- 
równania muzyczne - wspinaczka partnerów związanych liną jest ukazana jako „koncert na dwóch”. Istota przeżycia górskiego, obok kreacji, polega na trudnym do uchwycenia stopie "fizycznego z metafizycznym", "biologii z duchowością" [W, s. 12], dla "człowieka gór" jest to skoncentrowane życie.

W opowiadaniach Jagiełły poszukiwania tożsamościowe „ludzi gór" często są zwielokrotnione przez figurę (bardziej lub mniej dosłownej) amnezji, zagubienia i braku wiedzy o sobie samym. Bohater opowiadania Pod powierzchniq zadając sobie pytania („A co ze mną?", "Gdzie ja jestem?" ${ }^{47}$ ) i ze strzępów wspomnień "odtwarza" wiedzę o samym sobie. Ale w gruncie rzeczy pewnikiem jest tylko to, że ,jest wrażliwy na górską przyrodę i łatwo wpada w zdziwienie nad jej tajemniczym pięknem", poza tym jest nieszczęśliwie "zaplątany w sobie" ${ }^{48}$. W Czytaniu jaskini - innym opowiadaniu z tomu Trójkątna turnia, dylematy tożsamościowe przyjmują postać swego rodzaju wiwisekcji. „Doświadczony człowiek gór”, który „leczył się górami”, odprawiając swoje "najbardziej osobiste rekolekcje”, zanurza się nie tyle w czeluść jaskini, ile w samego siebie ${ }^{49}$. Narracja tożsamościowa w scenerii tatrzańskich podziemi staje się gęsta, niejasna, realne doznania mieszają się ze wspomnieniami, snami, zwidami. Autorefleksja odsłania coraz większe zagubienie, zapętlenie $\mathrm{w}$ sobie podmiotu, górsko-jaskiniowa terapia nie przywraca mężczyzny światu, lecz jeszcze bardziej go zamyka w sobie samym.

W sposób szczególny dylematy tożsamościowe "człowieka gór" wybrzmiewają w ostatnim, wydanym już po śmierci tomie Michała Jagiełły Pusta drabina ${ }^{50}$. Wiążą się one wyraźnie z rozrachunkiem z samym sobą, pytaniem o sens i cenę dokonywanych wyborów. Dostrzec je można nie tylko we wprost zadawanych sobie pytaniach: „Kim jestem? Gdzie idę?” [Skoruszowy Burdel, albo Modlitwa..., Pd, s. 42] ${ }^{51}$, „A co ze mną" [Nalewka z miłości, Pd, s. 27], w szukaniu "pnia siebie" pomiędzy , ja” dzisiejszym i , ja” tamtym [Niewidzialne, Pd, s. 28]. Znaczącym, choć nieoczywistym na pierwszy rzut oka, sposobem refleksyjnego działania na instancji podmiotu stają się poetyckie obrazy gór i doświadczeń związanych ze wspinaczką bądź „sakramentem ratowania ludzi" [Wierność, Pd, s. 35]. Zestawianie aktu pisania ze wspinaczką i stosowanie górskiej metaforyki oddają procesy zarówno analizowania, jak i nieustannego kształtowania siebie. Można by tu mówić o swego rodzaju

\footnotetext{
47 M. Jagieło, Pod powierzchniq, w: tegoż, Trójkątna turnia, s. 7-8.

48 Tamże, s. 21.

49 M. Jagiełło, Czytanie jaskini, w: tegoż, Trójkątna turnia, s. 93, 97, 99, 101.

50 Cytaty z tego tomu lokalizuję bezpośrednio w tekście głównym, stosując skrót Pd.

51 Skoruszowy Burdel to położona na wysokości $1411 \mathrm{~m}$ niewielka polanka w słowackich Tatrach Wysokich.
} 
"tożsamości w odbiciu". Skoncentrowany na górach podmiot niejako odbija się od nich, efektem doświadczenia świata wierchów jest samoobserwacja i autoanaliza. Wspinaczkowa lina często jest zarazem liną (nitką) życia, bywa "liną codziennego heroicznego sensu - na uwięzi zwyczajnego życia" [Lina na uwięzi, Pd, s. 6], wiążącą z innymi (rodziną, ukochaną osobą). „Człowiek gór" swoją egzystencję widzi w rytmie wspinania się i schodzenia:

Wejść w uprząż, dopieścić linę wychuchanym

Węzłem.

I w górę. I w zjazd. Twarzą w twarz. Skałą i lodem.

[Lina - na uwięzi, Pd, s. 6]

Podmiot wierszy Michała Jagiełły poszukuje siebie „w obliczu gór", $\mathrm{w}$ tej przestrzeni jest „z własnego wyboru”. O zadomowieniu w ,świecie wierchów" świadczy duża rola toponimii, zwłaszcza tatrzańskie oronimy nazwy gór są "smakowane" i poetycko „wygrywane” na różne sposoby ${ }^{52}$. $\mathrm{W}$ ostatnim tomie jednak jest ich nieco mniej niż w poprzednich zbiorach, oddaje to być może stopniowe oddalanie się od gór bezpośrednio doświadczanych podczas wędrówek, realnych i wymuszone wiekiem skoncentrowanie się na wierchach wspominanych, uwewnętrznionych. W hierarchii wartości "człowieka gór" wysoko ulokowane zostało poczucie wolności, które daje świat wierchów, dlatego tak boleśnie odczuwane są ograniczenia związane z wiekiem - ze wstępowaniem na "schyłkowy upłaz":

Stary wyznawca pańszczyzny wolności odpoczywa na co dopiero wzniesionej granicy.

[Elegia na głupawkę, Pd, s. 15]

W całym tomiku silnie obecne są wątki senilne. Świadomość wejścia na "grań życia", która może być granią ostatnią, wyraźnie stematyzowana została w utworze Jak długo jeszcze:

Ta lina ma już niemal pół wieku, wciąż szoruje lodową ścianą i zmrożonym śnieżnym filarem. Jak długo - jeszcze.

$$
\text { [Jak długo - jeszcze, Pd, s. 38] }
$$

W wierszach $\mathrm{z}$ tomu Pusta drabina podmiot - mimo barier stawianych przez starzejące się ciało - afirmuje "górskie życie", jest przekonany, że

52 Na przykład jeden z wierszy niemal w całości tworzą oronimy - M. Jagiełło, Osobowość artystyczna, w: tegoż, Ciało i pamięć. Wiersze, s. 46. 
„w każdym skrawku tych gór może się schować przed rozpaczą" [Na wietrze (niemota), Pd, s. 39]. Górska przyroda jest w wierszach Michała Jagiełły partnerem, rozmówcą, mentorem i pouczającym przewodnikiem:

Ja, Pinus cembra, radzę ci, homo sapiens:

Dziękuj losowi. Nie bądź zachłanny. To grzech.

Nie trać czasu. Poleruj Obdarowanie całym sobą.

[Lustro ulewy, Pd, s. 50]

Nawet znane miejsca są $\mathrm{w}$ wierszach taternika odkrywane na nowo i postrzegane jako "dar", wzbudzają wdzięczność, tym większą, że coraz wyraźniejsza wydaje się świadomość końca wędrówki „w górę” i „w dół” [Dopóki... $w$ górę, w dót, Pd, s. 51].

Właściwie syntezą tożsamości i mitologii „człowieka gór” w późnej poezji Michała Jagiełły jest lapidarny wiersz Uważać na wykrzyknik!:

Umiarkowane wyważone oszukiwane.

Ja! (Uważać na wykrzyknik).

Lęk na asekuracji.

Osobowość artystyczna zwietrzała, skwaśniały nektar upartej niedojrzałości.

[Uważać na wykrzyknik!, Pd, s. 46]

W dwóch pierwszych wersach dostrzegam ślady procesów tożsamościowych. Utwór rozpoczyna się od wyliczenia określeń odnoszących się do ,ja". Lecz nie jest to charakterystyka, raczej widziałabym w tym enumeracyjnym toku zapis pewnych tożsamościowych złudzeń, samooszukiwań związanych z próbami ujęcia samoidentyfikacji w pewne ramy tak, żeby ,ja” było „umiarkowane" i „wyważone”. Jednak owo ,ja” zdaje się wymykać spod kontroli, emocje ujawniają się $\mathrm{w}$ postawionym po nim wykrzykniku. Wtrącenie $\mathrm{w}$ nawiasie jest zwrotem do „siebie”, upomnieniem „siebie”. W przejściu od „ja” do „siebie” właśnie dostrzec można, tak charakterystyczne dla czasów obecnych, wątpliwości związane z podmiotowością opartą na stabilnych podstawach, skłaniające do postrzegania jej bardziej w kategoriach procesualnych czy narracyjnych ${ }^{53}$. Tożsamościowe wahania i poszukiwania dokonują się w odniesieniu do przestrzeni górskiej, która jednak w liryku jest jedynie zamarkowana wersem o „lęku na asekuracji”. Zamiast opisu gór jest sygnał

53 Szeroko pisze na ten temat, omawiając różne koncepcje R. Sendyka, Od kultury ja do kultury siebie. O zwrotnych formach w projektach tożsamościowych, Kraków 2015. 
pewnych doznań cielesnych i emocji na granicy świadomości. We wspomnianym lęku mogą zawierać się różne (nie tylko "górskie”) rozterki czy pamięć o niepowodzeniach i błędach, o braku poczucia bezpieczeństwa nawet „na asekuracji”, która właśnie bezpieczeństwo powinna gwarantować. „Lęk na asekuracji" jest zastanawiający, choć wydaje się nieodłącznie związany z górską aktywnością. Walter Bonatti w klasycznej dla "miłośników gór” książce Moje góry pisze, że lęk jest „jednym z wielu uczuć, jakich doznaje alpinista - a wszystkie one dają mu odczuć smak życia. Byłoby źle, gdyby w górach nie odczuwało się lęku. Byłoby to równoznaczne z nieświadomością, odbierałoby największą radość, jaką daje przezwyciężanie siebie" ${ }^{54}$.

W ostatnich wersach lapidarnego liryku Jagiełly „lęk na asekuracji” współbrzmi z autoironią. Dystans do własnych górskich dokonań, ale i do własnej twórczości („osobowość artystyczna zwietrzała”) wyróżnia utwory Michała Jagiełły na tle piśmiennictwa alpinistycznego. Wcześniej, w Wołaniu $w$ górach pisarz zauważył:

Najcenniejsza zdobycz, jaką możemy wynieść z gór, to spojrzenie na siebie z dystansu. Zazwyczaj pomocna w tym jest jednak „smuga cienia”. Może nią być poważnie przeżyty kontakt ze śmiercią, może też rolę katalizatora wewnętrznych procesów odegrać niepowodzenie górskie [W, s. 354].

W zamykającym życie i twórczość tomie Pusta drabina, "człowiek gór" przyznaje autokrytycznie, że mimo wieku i bagażu doświadczeń nie opuszcza go "górska chcica" [Dopóki... w górę, w dót, Pd, s. 51], że uległ "górskiej głupawce", schodząc z bezpiecznego szlaku [Elegia na głupawke, Pd, s. 14], pisze o "nalewce z miłości własnej” [Nalewka z miłości, Pd, s. 27]. Ironię dostrzec można także $\mathrm{w}$ wątkach autotematycznych, w wyrażaniu poczucia własnej artystycznej "niemoty”, wątpliwości, czy można w ogóle dosięgnąć istoty górskiego przeżycia, czy nie jest ono jedynie przykrywane "sentymentalnym kożuchem obrazów” i „zużytych słów” [Suche wody, Pd, s. 22]:

Tyle dni w górach - czysta perwersja.

Odłupuję grube warstwy narosłe

Na tutejszej przyrodzie i próbuję

Nakrywać je swoją płachtą utkaną

Z nieporadnych słów.

[Błogosławiony grzech, Pd, s. 11]

Nawiązując do rozróżnień zaproponowanych przez Romę Sendykę, można by powiedzieć, że Jagiełło jest zdecydowanie bardziej epizodykiem

54 W. Bonatti, Moje góry, s. 6. 
niż diachronikiem ${ }^{55}$. Poeta nie tyle buduje koherentną opowieść o sobie jako „człowieku gór", ile raczej zestawia obrazy-wspomnienia (odnaleźć je można w licznych wierszach takich, jak: Rękawiczki 1979 czy Biedronki 1982 $\mathrm{z}$ tomu Ciało i pamięćc $\left.{ }^{56}\right)$, które dają pewne, minimalne poczucie ciągłości siebie. Poetycki dyskurs tożsamościowy nie jest zwieńczony poczuciem dopełnienia , ja”, lecz kończy go uwaga o „upartej niedojrzałości”.

Przestrzeń górska pozwala doświadczyć życia w esencjonalny sposób, ale to doświadczenie bywa "oplecione zwojami alpinistycznej mitologii" [To bardziej ryzykowne..., Pd, s. 24]. Jednak to właśnie $\mathrm{w}$ takim odniesieniu i w taki sposób przebiega w poezji Michała Jagiełły proces samoidentyfikacji podmiotu. Poszukiwania i złudzenia, krzyk i lęk, przechodzenie od „ja" do "siebie”, a w tle góry, a dokładniej „moje góry”, a jeszcze inaczej: Kościelec i Czuba Goryczkowa, Krzesanica i Rozpadła Grań, Ciemniak i Twardy Upłaz... Nawiązując do tytułu jednego ze wcześniejszych tomików poetyckich tego autora: Zszywanie - w ucieczce, można stwierdzić, że w Pustej drabinie widoczne jest "zszywanie" siebie w ucieczce przed sobą samym (przed „małym namolnym ja”) przed tym, co nieuchronne, co przerwie rytm wchodzenia na szczyty i schodzenia w doliny. Choć "zszywanie” dokonywane w procesie samoidentyfikacji "człowieka gór" jest dramatyczne, to jednak ukazane zostało z dystansem, a nawet ironią. Przede wszystkim "goryczka", która jest obok "słodyczki”, nie przysłania tego, co w twórczości Michała Jagiełly chyba najistotniejsze - postawy afirmatywnej wobec gór i życia samego.

\section{Bibliografia}

Bilczewski Adam (1987), Alpiniści, Katowice: Krajowa Agencja Wydawnicza.

Bonatti Walter (1967), Moje góry, przeł. B. Norton, Warszawa: Iskry.

Czermińska Małgorzata (2013), Tożsamość kształtowana w pamięci miejsca, „Ruch Literacki", nr 6, s. 591-606.

\footnotetext{
55 „Epizodyk nie ujmuje siebie »jako rzeczy, która istniała w (dalszej) przeszłości i będzie tu w (dalszej) przyszłości«. Epizodyk ma oczywiście świadomość ciągłości i całości »osoby ludzkiej «, nie myli jednak tego aspektu z ciągłością "poczucia siebie «" [R. Sendyka, Od kultury ja do kultury siebie. O zwrotnych formach w projektach tożsamościowych, s. 384]. „Diachronicy natomiast ujmują siebie jako byt o długoterminowej trwałości: to pro-narracyjna większość, która podziela przekonanie, że jesteśmy stworzeni jako wirtuozerscy opowiadacze, tworzący własne historie w nieustannym wysiłku narzucania koherencji na materiał życia" [tamże, s. 385].

56 M. Jagiełło, Rękawiczki 1979, w: tegoż, Ciało i pamięć. Wiersze, s. 16; tegoż, Biedronki 1982, w: tegoż, Ciało i pamięć. Wiersze, s. 17.
} 
Dutka Elżbieta (2017), Ekstremalne doświadczenia w ekstremalnej „wcieleniówce”. „Długi film o miłości. Powrót na Broad Peak" Jacka Hugo-Badera jako opowieść o niespełnieniu, „Białostockie Studia Literaturoznawcze”, nr 11, s. 257-274.

Hugo-Bader Jacek (2014), Długi film o miłości. Powrót na Broad Peak, Kraków: Wydawnictwo Znak.

Jagiełło Michał (1978), Hotel klasy lux, Warszawa: Czytelnik.

Jagiełło Michał (1991), Czerwień i czerń. Z Michałem Jagiełła rozmawia Wacław Sonelski, „Bularz”, s. 18-25.

Jagiełło Michał (1994), Obsesja i inne góry, Warszawa: Bellona.

Jagiełło Michał (1996), Trójkątna turnia, Warszawa: Iskry.

Jagiełło Michał (1998), Za grania grań, Warszawa: Iskry.

Jagiełło Michał (2000), Jawnie i skrycie, Warszawa: Iskry.

Jagiełło Michał (2007), Goryczka, słodyczka, czas Opowieści, Torun: Wydawnictwo Adam Marszałek.

Jagiełło Michał (2008), Sosna i pies. Poemat z zagrody, Warszawa: Iskry.

Jagiełło Michał (2010), Ciało i pamięć, Warszawa: Iskry.

Jagiełło Michał (2012), Tatry. Koncert na dwóch, zdjęcia K. Wojnarowski, Kraków: Wydawnictwo Astraia.

Jagiełło Michał (2012), Wołanie w górach. Wypadki i akcje ratunkowe w Tatrach, Warszawa: Iskry.

Jagiełło Michał (2014), Osobowość artystyczna w górach wysokich, „Nowe Książki”, nr 9, s. 64-65.

Jagiełło Michał (2014), Zszywanie - w ucieczce, Warszawa: Iskry.

Jagiełło Michał (2016), Pusta drabina, Warszawa: Iskry.

Kaczmarek Jacek (2005), Podejście geobiograficzne w geografii społecznej. Zarys teorii i podstawy metodycznej, Łódź: Wydawnictwo Uniwersytetu Łódzkiego.

Kalicki Włodzimierz (2007), Między górami a bibliotekami, w: Sztambuch Michała Jagiełty, autor pomysłu R. Monity, red. K. Wiwer, Kraków: Wydawnictwo Astraia, s. 56.

Kalota-Szymańska Maria (1981), Sezon w Tatrach i po sezonie, Gdańsk: Wydawnictwo Morskie.

Kalus Ewa (2016), Skalne olśnienia. Współczesna poezja tatrzańsko-podhalańska, Kraków: Księgarnia Akademicka.

Kiełkowska Małgorzata, Kiełkowski Jan [red.] (2013), Wielka encyklopedia gór i alpinizmu, t. 6: Ludzie gór, Katowice: Wydawnictwo Stapis.

Kijonka Justyna (2016), Tożsamość współczesnych Górnośląaków. Studium socjologiczne, Katowice: Wydawnictwo "Śląsk”.

Klemensiewicz Zygmunt, Społeczna wartość taternictwa, w: Czarny szczyt. Proza taternicka lat 1904-1939, wybór, oprac. i przedm. J. Kolbuszewski, Kraków: Wydawnictwo Literackie 1976, s. 87-93.

Kolbuszewski Jacek (1976), Przedmowa, w: Czarny szczyt. Proza taternicka lat 1904-1939, wybór, oprac. i przedm. J. Kolbuszewski, Kraków: Wydawnictwo Literackie, s. $5-23$.

Kolbuszewski Jacek (1995), W stronę współczesności, w: tegoż, Tatry. Literacka tradycja motywu gór, Kraków: Oficyna Podhalańska, s. 145-169. 
Krajewski Stanisław (2007), O Michale osobiście, w: Sztambuch Michała Jagiełty, autor pomysłu R. Monity, red. K. Wiwer, Kraków: Wydawnictwo Astraia, s. 76.

Krygowski Władysław (1977), Góry i doliny po mojemu, Kraków: Wydawnictwo Literackie.

Kunce Aleksandra (2016), Człowiek lokalny. Rozważania umiejscowione, Katowice: Wydawnictwo Uniwersytetu Śląskiego.

Madurowicz Mikołaj (2006), Tożsamość homo localis w geografii człowieka, w: Człowiek w badaniach geograficznych, red. W. Maik, K. Rembowska, A. Suliborski, Bydgoszcz: Wydawnictwo Uczelniane Wyższej Szkoły Gospodarki.

Malczewski Rafał (1928), Narkotyk gór. Nowele, Warszawa: Wydawnictwo Gebethnera i Wolffa.

McDonald Bernadette (2018), Kurtyka. Sztuka wolności, przeł. M. Krupa, Warszawa: Wydawnictwo Agora.

Mikucki Krzysztof [oprac.] (2011), Miłość gór, Kraków: Wydawnictwo WAM.

Mikucki Krzysztof [oprac.] (2017), Potęga gór, zdjęcia P. Dróżdż, Kraków: Wydawnictwo Stapis.

Ogłoza Ewa (2017), Wieś, Tatry i słowo w liryce Michała Jagiełly, w: Między sacrum i profanum. Rozważania i dylematy, red. G. Różańska, Kraków: „Dante”, s. 41-61.

Pawlikowski Jan Gwalbert (2010), Kultura a natura i inne manifesty ekologiczne, wybór, oprac., red. R. Okraska, Łódź: Stowarzyszenie „Obywatele Obywatelom”.

Ptakowska-Wyżanowicz Halina (1960), Od krynoliny do liny, Warszawa: Sport i Turystyka.

Rewers Ewa (2000), Miejsce podmiotu - podmiot jako miejsce. Kto wyprowadza podmiot $z$ metafizyki?, „Er(r)go", nr 1, s. 21-34.

Rewers Ewa (2004), Więźniowie transkulturowej wyobraźni, „Teksty Drugie”, nr 4, s. $28-39$.

Rybicka Elżbieta (2014), Geopoetyka. Przestrzeń i miejsce we wspótczesnych teoriach i praktykach literackich, Kraków: Universitas,.

Sebesta Antonina (2014), Etyka i ethos „ludzi gór”, Zakopane: Fundacja im. Zofii i Witolda Paryskich.

Sendyka Roma (2015), Od kultury ja do kultury siebie. O zwrotnych formach w projektach tożsamościowych, Kraków: Universitas.

Wiwer Katarzyna [red.] (2007), Sztambuch Michała Jagiełly, autor pomysłu R. Monity, Kraków: Wydawnictwo Astraia.

Wojciechowski Aleksander (1982), Tatrzańskie, Poznań: Wydawnictwo Poznańskie.

Wojsznic Justyn (1994), [wstęp], w: G. Rébuffat, Gwiazdy i burze. Sześć północnych ścian alpejskich, przeł. Jerzy Kolankowski, Londyn-Kraków: Wydawnictwo At Publications, s. 5-12.

Zaruski Mariusz (2007), Na bezdrożach tatrzańskich. Wycieczki, wrażenia i opisy, Łomianki: Wydawnictwo LTW.

Zawadzka Danuta, Mikołajczak Małgorzata, Sawicka-Mierzyńska Katarzyna [red.] (2016), Region a tożsamości transgraniczne. Literatura. Miejsca. Translokacje, Kraków: Universitas. 
Żuławski Wawrzyniec (1967), Wędrówki alpejskie, w: W. Żuławski, Sygnały ze skalnych ścian, Tragedie tatrzańskie, Wędrówwi alpejskie, Skalne lato, Warszawa: Nasza Księgarnia.

http://www.wgorach.art.pl

www.portalgorski.pl/artykuly/ludzie-gor

\title{
Space and Identity: Dilemmas of the "Mountain Man" in the Works of Michał Jagiełło
}

\begin{abstract}
The article discusses the problem of relations between spatial issues and contemporary identity discourses. Using such concepts as homo geographicus (R.D. Sack and J. Kaczmarek) and homo localis (M. Madurowicz), it presents a special case in which the subjectivity is determined in relation to the specific geographical environment - the mountains. The term "mountain man", used in the literature, media and colloquial language for more than a hundred years, was analyzed from a philosophical perspective by Antonina Sebesta in the work Etyka i ethos "ludzi gór" (Ethics and Ethos of "Mountain People"). However the definition and scope of this identity category remains undetermined. This article "puts to test" the concept of the "mountain man" by analyzing the works of the so-called "mountain literature" of Michał Jagiełło - literary critic, mountaineer and rescue team member. The interpretations of the poems concentrate on the role of spatial metaphors in the lyrical identity narrative. The author notes how Jagiełło's works, especially his last book of poetry - Pusta drabina [The Empty Ladder] encourage reflection on identity and the mythology of the "mountain man".
\end{abstract}

Keywords: mountains in literature, geographical space, autobiographical writing, geopoetics, spatial metaphors 